\title{
Fungicidal effect of some non-conventional chemicals for management of alternaria blight disease of mustard
}

\author{
Amarendra Kumar ${ }^{1 *}$, Santosh Kumar ${ }^{1}$, Rakesh Kumar ${ }^{2}$, Gireesh Chand ${ }^{1}$ and S. J. Kolte ${ }^{3}$ \\ ${ }^{1}$ Department of Plant Pathology, Bihar Agricultural University, Sabour, Bhagalpur-821310 (Bihar), INDIA \\ ${ }^{2}$ Department of Soil Science and Agricultural Chemistry, Bihar Agricultural University, Sabour, Bhagalpur \\ -821310 (Bihar), INDIA \\ ${ }^{3}$ Department of Plant Pathology, Govind Ballabh Pant University of Agriculture \& Technology, Pantnagar -263145 \\ (Uttarakhand), INDIA
}

"Corresponding author. E-mail: rbinnu@gmail.com

Received: August 8, 2014; Revised received: September 13, 2014; Accepted: December 20, 2014.

\begin{abstract}
Alternaria blight disease of mustard caused by a necrotrophic fungus Alternaria brassicae (Berk.) Sacc. is one of the most important limiting factors, causing yield losses of up to $47 \%$ in mustard (Brassica juncea). The aim of this present investigation was to evaluate the fungicidal effect of non-conventional chemicals viz. calcium sulphate $\left(\mathrm{CaSO}_{4}\right)$, potassium chloride $(\mathrm{KCl})$, potassium sulphate $\left(\mathrm{K}_{2} \mathrm{SO}_{4}\right)$, zinc sulphate $\left(\mathrm{ZnSO}_{4}\right)$ and borax $\left(\mathrm{Na}_{2} \mathrm{~B}_{4} \mathrm{O}_{7} .10 \mathrm{H}_{2} \mathrm{O}\right)$ against alternaria blight disease of mustard. The significantly minimum size of spot was recorded in $\mathrm{T}_{1} \mathrm{CaS}$ at $0.5 \%$ (1.73) followed by $\mathrm{T}_{3} \mathrm{CaS}$ at $1.5 \%(1.75)$ and $\mathrm{T}_{2} \mathrm{CaS}$ at $1.0 \%$ (1.78) respectively in comparison to check. The minimum number of average leaf spots $/ 25 \mathrm{~mm}^{2}$ leaf area was observed in $\mathrm{T}_{3} \mathrm{CaS}$ at $1.5 \%$ (1.78) followed by $\mathrm{T}_{1} \mathrm{CaS}$ at $0.5 \%$ (2.26). $\mathrm{T}_{1} \mathrm{CaS} @$ at $0.5 \%$ showed significantly lowest disease index (13.00\%) followed by $\mathrm{T}_{15} \mathrm{NaB}$ at $0.75 \%(17.77 \%)$ and $\mathrm{T}_{8} \mathrm{KS}$ at $1.0 \%(18.00 \%)$ respectively over check. The average minimum apparent infection rate was recorded in $\mathrm{T}_{1} \mathrm{CaS}$ at $0.5 \%$ ( 0.504$)$ followed by $\mathrm{T}_{9} \mathrm{KS}$ at $1.5 \%(0.553)$ and $\mathrm{T}_{3} \mathrm{CaS}$ at $1.5 \%(0.573)$ respectively. The AUDPC was significantly minimum in all the treatments of $\mathrm{CaSO}_{4}$ i.e. in $\mathrm{T}_{1} \mathrm{CaS}$ at $0.5 \%(32.25), \mathrm{T}_{2} \mathrm{CaS}$ at $1.0 \%(33.8)$ and $\mathrm{T}_{3} \mathrm{CaS}$ at $1.5 \%$ (35.55) in comparison to check (77.95). The foliar spray of $\mathrm{CaSO}_{4}$ at $0.5 \%$ concentration induced resistance significantly against alternaria blight and reduce pesticide residue in food and environment.
\end{abstract}

Keywords: Alternaria blight, Alternaria brassicae (Berk.) Sacc., Mustard, Non-conventional chemicals

\section{INTRODUCTION}

Mustard (Brassica juncea (Linn.) Czern. and Coss.) is an important oil seed crop, grown both in tropical and sub tropical regions of the world. Among the biotic factors, fungal diseases alone are responsible for severe damages to the crop resulting in yield losses up to $70 \%$ on a world wide scale. Amongst the major fungal diseases of oilseed brassicas prevalent in India, alternaria blight disease is the most important and destructive disease causing heavy losses all over the world attacking all Brassica species (Kolte, 1985; Meena et al., 2010). Alternaria blight disease caused by Alternaria brassicae (Berk. and Sacc.) has been reported from all the continents of the world and is one among the important diseases of Indian mustard causing up to $47 \%$ yield losses with no proven source of resistance against the disease reported till date in any of the hosts (Meena $e t$ al., 2010; Meena et al., 2012). This disease appears on leaves and stems of seedlings and adult plants and also in siliquae during the ripening stage. Dark spots on the leaves and siliquae reduce the photosynthetic capacity and induce immature ripening, which causes reduced amount of quality seed production in both vegetable and oleiferous brassicas (Kumar et al., 2014).

Alternaria blight disease management mainly relies on fungicide applications. A large number of fungicides have been reported to be effective management of the disease under field conditions viz. Baycor $(0.2 \%)$, Blitox $50(0.3 \%)$, Dithane M45 (0.2\%), Dithane Z78(0.2\%), Rovral 50 (0.2\%), Ridomil MZ (Mancozeb 64\% +Metalaxyl 8\% WP) etc. (Verma and Saharan, 1994; Khan et al., 2007; Sultana et al., 2009). Although these chemicals found to be effective but leads to residual toxicity, development of resistance in the target organisms and also affect the oil quality in oilseed brassicas (McCartney et al., 1999). The injudicious and unplanned application of fungicides cause health hazards and create environmental pollution. Non-conventional chemicals provide nutrients to the host plant which affect the relationship between crop and pathogen in many ways. It is apparent that plant nutrition is one of the environmental factors which along with others, such as temperature, humidity, moisture and soil reaction may have a measurable effect upon the course of disease development. The present investigations were conducted to find out some 
inexpensive, non-toxic, non-conventional chemical compounds as abiotic elicitors of $B$. juncea in relation to activate defence response as possible alternative in the management of alternaria blight.

\section{MATERIALS AND METHODS}

A field isolate of Alternaria brassicae from infected leaves exhibiting typical symptoms of Alternaria spot, usually with concentric rings, was collected from the field-grown plants of highly susceptible $B$. juncea $\mathrm{cv}$. Varuna from Crop Research Centre, Pantnagar. The culture of A. brassicae was isolated on potato sucrose agar (PSA) and purified by single spore isolation. The pathogen was maintained on potato sucrose agar (PSA) medium at $20^{\circ} \pm 2{ }^{\circ} \mathrm{C}, 12 \mathrm{hrs}$ light and 12 hrs dark conditions. Pathogenicity test of the fungal culture was done on one-month-old highly susceptible $B$. juncea.

Alternaria blight susceptible mustard variety varuna was used in the glasshouse experiments. Freshly collected field soil (sandy loam) was mixed with compost in $3: 1$ proportion, sieved through $0.2 \mathrm{~mm}$ sieve and was filled in the pot which were used for sowing. Two gram diammonium phosphate (DAP) was mixed in each pot before sowing.

Two-week-old culture on PSA medium was taken and blended with the Blender in $250 \mathrm{ml}$ sterilized water. The concentration was adjusted to $10^{4}$ spores $\mathrm{ml}^{-1}$. The suspension was sprayed on 25-day-old plants using atomizer. Control plants were sprayed with sterilized water. Inoculated plants were incubated for 3 days in the humid chamber at $90-100 \%$ R.H. After 3 days, pots were kept outside the glasshouse under normal conditions, at the temperature ranging between minimum of $8^{\circ} \mathrm{C}$ and maximum of $22^{\circ} \mathrm{C}$ during the month of January for development of the symptoms. The fungus was re-isolated from infected leaves and maintained on PSA slants and pathogenecity test, as above, was reported twice to confirm the results.

A total of five chemicals viz. $\mathrm{CaSO}_{4}(\mathrm{CaS}), \mathrm{KCl}(\mathrm{Kl})$, $\mathrm{K}_{2} \mathrm{SO}_{4}(\mathrm{KS}), \mathrm{ZnSO}_{4} \cdot 7 \mathrm{H}_{2} \mathrm{O}(\mathrm{ZnS})$, and $\mathrm{Na}_{2} \mathrm{~B}_{4} \mathrm{O}_{7} \cdot 10 \mathrm{H}_{2} \mathrm{O}$ $(\mathrm{NaB})$ were tested as spray treatments with three different concentrations. Two sprays of each chemical of the respective concentrations were given during the entire growth period of plants with an atomizer. Separate atomizer was used for each chemical. First spray of respective chemicals was given on all the leaves of 25-day-old plants i.e. $72 \mathrm{hrs}$ of pre-inoculation and the second spray was given after $72 \mathrm{hrs}$ of post-inoculation.

Size of spot was recorded in randomly selected five spots/leaf was measured in mm including yellow halo, chlorotic area with necrotic brown area in the centre at 10 days interval. The numbers of spots on leaf per 25 $\mathrm{mm}^{2}$ leaf area were recorded at 10 days interval with the help of a glass slide. Observations were taken on five leaves and average number of spots per $25 \mathrm{~mm}^{2}$ area was then calculated. Average disease index on leaf due to Alternaria blight was taken at 10 days interval by use of $0-5$ rating scale as $0=$ no symptom, $1=1-10 \%$, $2=11-25 \%, 3=26-50 \%, 4=51-75 \%$ and $5=>75 \%$ (Conn et al., 1990). For recording observations, five leaves were selected from each replication randomly and leaves were rated as per the above scale and average disease index was calculated by the following formula (McKinney, 1923):

Disease index $(\%)=\frac{\text { Sum of all numerical rating }}{\text { Number of leaves examined } \times \text { Maximum grade }} \times 100$

Apparent infection rates were calculated from the disease index at different times and subsequent infection rate (r) was calculated by using formula given by Vanderplank (1963).

$$
r=\frac{2.3}{t_{2}-t_{1}} \log _{10} \frac{x_{2}\left(1-x_{1}\right)}{x_{1}\left(1-x_{2}\right)}
$$

Where,

$$
\begin{aligned}
& \mathrm{r}=\text { apparent infection rate } \\
& \mathrm{x}_{1}=\text { disease index at time } \mathrm{t}_{1} \\
& \mathrm{x}_{2}=\text { disease index at time } \mathrm{t}_{2} \\
& \mathrm{t}_{1}=\text { time of initial disease rating }\left(\mathrm{x}_{1}\right) \\
& \mathrm{t}_{2}=\text { time of second disease rating }\left(\mathrm{x}_{2}\right)
\end{aligned}
$$

For comparative study of disease progress in different treatments, the area under disease progress curve (AUDPC) was calculated for each treatment using formula given by Wilcoxson et al. (1975) which are as follows:

Where,

$$
\sum_{i-1}^{K} \frac{1}{2}\left(S_{i}+S_{i-1}\right) d
$$

$\mathrm{S}_{\mathrm{i}}=$ Disease severity at the end of week $\mathrm{i}$

$\mathrm{K}=$ Number of successive evaluation of disease $\mathrm{d}=$ Interval between two evaluations.

Area under disease progress curve was plotted by plotting time interval on $\mathrm{x}$-axis and size of spot $(\mathrm{mm})$ on $\mathrm{Y}$-axis in respect of different treatments.

\section{RESULTS AND DISCUSSION}

The present investigations were conducted to find out the fungicidal effect of some inexpensive, non-toxic, non-conventional chemical compounds as possible alternative in the management of alternaria blight disease of mustard. Size of alternaria leaf spot due to some non -conventional chemicals was measured from 30 to 50 days after sowing at 10 days interval. The size of leaf spot increased from 30 Days after sowing (DAS) to 50 DAS in all the treatments. Minimum size of spot (1.73 to $1.78 \mathrm{~mm}$ ) was found significant in all three treatments of $\mathrm{CaSO}_{4}$. The maximum reduction of size of spot was recorded in $\mathrm{T}_{1} \mathrm{CaS}$ (52.20) followed by $\mathrm{T}_{3} \mathrm{CaS}$ (51.65) and $\mathrm{T}_{2} \mathrm{CaS}(50.82 \%)$, respectively over check. The maximum average size of leaf spot was observed in check $(3.62 \mathrm{~mm})$.The interactions between different treatments and observation intervals was also found significant (Table 1). 


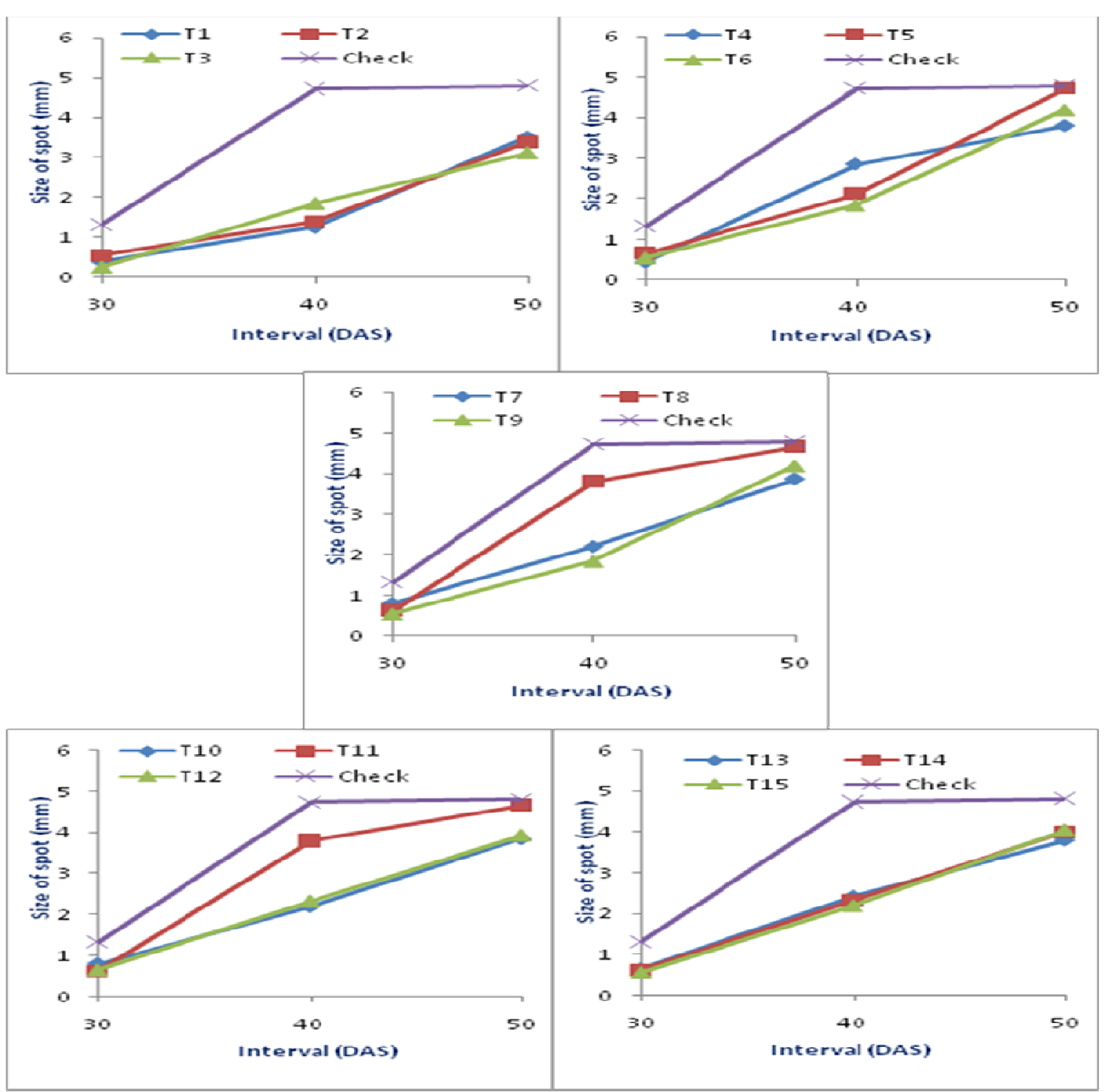

Fig. 1. Effect of some non-conventional chemicals on AUDPC of A. brassicae in relation to size of spot (mm) in mustard.

Average number of leaf spots $/ 25 \mathrm{~mm}^{2}$ leaf area also progressively increased from 30 to 50 DAS in all the treatments (Table 2). The increase of number of leaf spots per $25 \mathrm{~mm}^{2}$ leaf area was found to be highly significant at $1 \%$ level among the treatments and observation intervals. The interactions among these variable were also highly significant. The significantly minimum number of average leaf spots/25 $\mathrm{mm}^{2}$ leaf area was observed in $\mathrm{T}_{3} \mathrm{CaS}$ at $1.5 \%$ (1.78) followed by $\mathrm{T}_{1} \mathrm{CaS}$ at $0.5 \%$ (2.26) in comparison to check (5.06).

The leaf disease index was found to be highly significant among the treatments as well as between observation intervals and their interactions. Among the treatments, $\mathrm{T}_{1} \mathrm{CaS}$ at $0.5 \%$ showed lowest disease index $(13.00 \%)$ followed by $\mathrm{T}_{15} \mathrm{NaB}$ at $0.75 \%(17.77 \%)$ and $\mathrm{T}_{8} \mathrm{KS}$ at $1.0 \%(18.00 \%)$ respectively over check at $5 \%$ level of significance. The maximum disease index was observed in $\mathrm{T}_{10} \mathrm{ZnS}$ at $0.25 \%$ (25.00\%) followed by $\mathrm{T}_{12} \mathrm{ZnS}$ at
$0.75 \%(23.55 \%)$ and $\mathrm{T}_{4} \mathrm{Kl}$ at $0.5 \%(23.11 \%)$ respectively over check (Table 3 ).

The Apparent infection rate progressively increased between 30-40 DAS and 40-50 DAS in all the treatments. The maximum apparent infection rate was observed in check within 30-40 and 40-50 DAS i.e. 0.661 and 0.796, respectively. Based on overall mean of apparent infection rate, the minimum apparent infection rate was recorded in $\mathrm{T}_{1} \mathrm{CaS}$ at $0.5 \%$ ( 0.504 ) followed by $\mathrm{T}_{9} \mathrm{KS}$ at $1.5 \%$ $(0.553)$ and $\mathrm{T}_{3} \mathrm{CaS}$ at $1.5 \%$ (0.573), respectively over check (Table 4).

The area under disease progress curve (AUDPC) was measured for different treatments (Fig.1). It was observed that the AUDPC was significantly minimum in all the treatments of $\mathrm{CaSO}_{4}$ i.e. in $\mathrm{T}_{1} \mathrm{CaS}$ at $0.5 \%$ (32.25), $\mathrm{T}_{2}$ $\mathrm{CaS}$ at $1.0 \%$ (33.8) and $\mathrm{T}_{3} \mathrm{CaS}$ at $1.5 \%$ (35.55) in comparison to check (77.95) (Table 5). The maximum AUDPC was recorded in both treatments $\mathrm{T}_{8} \mathrm{KS}$ at 
Table 1. Effect of some non-conventional chemicals on size of alternaria leaf spot at different stages of growth of mustard.

\begin{tabular}{|c|c|c|c|c|c|c|}
\hline \multirow[t]{2}{*}{ Treatment } & \multirow[t]{2}{*}{ Concentration (\%) } & \multicolumn{2}{|c|}{ Size of leaf spot } & $(\mathrm{mm})$ & \multirow[t]{2}{*}{ Mean } & \multirow{2}{*}{$\begin{array}{l}\text { Reduction over } \\
\text { check }(\%)\end{array}$} \\
\hline & & $30 \mathrm{DAS}$ & 40 DAS & $50 \mathrm{DAS}$ & & \\
\hline $\mathrm{T} 1 \mathrm{CaS}$ & 0.5 & 0.40 & 1.26 & 3.53 & 1.73 & 52.20 \\
\hline $\mathrm{T} 2 \mathrm{CaS}$ & 1.0 & 0.56 & 1.40 & 3.40 & 1.78 & 50.82 \\
\hline $\mathrm{T} 3 \mathrm{CaS}$ & 1.5 & 0.26 & 1.86 & 3.13 & 1.75 & 51.65 \\
\hline $\mathrm{T} 4 \mathrm{Kl}$ & 0.5 & 0.46 & 2.86 & 3.80 & 2.37 & 34.53 \\
\hline T5 Kl & 1.0 & 0.66 & 2.13 & 4.73 & 2.51 & 30.66 \\
\hline T6 K1 & 1.5 & 0.56 & 1.86 & 4.20 & 2.21 & 38.95 \\
\hline T7 KS & 0.5 & 0.80 & 2.20 & 3.86 & 2.28 & 37.01 \\
\hline T8 KS & 1.0 & 0.63 & 3.80 & 4.66 & 3.03 & 16.29 \\
\hline T9 KS & 1.5 & 0.56 & 1.86 & 4.20 & 2.21 & 38.95 \\
\hline $\mathrm{T} 10 \mathrm{ZnS}$ & 0.25 & 0.80 & 2.20 & 3.86 & 2.28 & 37.01 \\
\hline $\mathrm{T} 11 \mathrm{ZnS}$ & 0.50 & 0.63 & 3.80 & 4.66 & 3.03 & 16.29 \\
\hline $\mathrm{T} 12 \mathrm{ZnS}$ & 0.75 & 0.66 & 2.33 & 3.93 & 2.31 & 36.18 \\
\hline T13 NaB & 0.25 & 0.66 & 2.43 & 3.80 & 2.30 & 36.46 \\
\hline $\mathrm{T} 14 \mathrm{NaB}$ & 0.50 & 0.63 & 2.33 & 4.00 & 2.32 & 35.91 \\
\hline T15 NaB & 0.75 & 0.56 & 2.20 & 4.06 & 2.27 & 37.29 \\
\hline $\mathrm{T}$ check & - & 1.33 & 4.73 & 4.80 & 3.62 & - \\
\hline $\begin{array}{l}\text { Mean C.D. } \\
\text { at 5\% }\end{array}$ & & 0.63 & 2.45 & 4.04 & & \\
\hline Treatment & & & & & 0.46 & \\
\hline Interval & & & & & 0.19 & \\
\hline Interaction & & & & & 0.79 & \\
\hline
\end{tabular}

Table 2. Effect of some non-conventional chemicals on number of alternaria leaf spots at different stages of growth of mustard.

\begin{tabular}{|c|c|c|c|c|c|c|}
\hline \multirow[t]{2}{*}{ Treatment } & \multirow[t]{2}{*}{ Concentration (\%) } & \multicolumn{2}{|c|}{$\begin{array}{l}\text { Number of leaf spots/ } \\
\text { area }\end{array}$} & \multirow{2}{*}{$\begin{array}{l}25 \mathrm{~mm} 2 \\
50 \mathrm{DAS}\end{array}$} & \multirow[t]{2}{*}{ Mean } & \multirow[t]{2}{*}{$\begin{array}{l}\text { Reduction over } \\
\text { check }(\%)\end{array}$} \\
\hline & & 30 DAS & 40 DAS & & & \\
\hline $\mathrm{T} 1 \mathrm{CaS}$ & 0.5 & 0.66 & 1.33 & 5.40 & 2.26 & 55.33 \\
\hline $\mathrm{T} 2 \mathrm{CaS}$ & 1.0 & 1.36 & 2.20 & 5.06 & 2.87 & 43.28 \\
\hline $\mathrm{T} 3 \mathrm{CaS}$ & 1.5 & 0.56 & 1.26 & 3.53 & 1.78 & 64.82 \\
\hline T4 K1 & 0.5 & 0.73 & 2.66 & 6.20 & 3.20 & 36.75 \\
\hline T5 Kl & 1.0 & 1.70 & 3.53 & 5.93 & 3.72 & 26.48 \\
\hline T6 K1 & 1.5 & 1.23 & 3.00 & 5.86 & 3.36 & 33.59 \\
\hline T7 KS & 0.5 & 1.03 & 2.53 & 6.66 & 3.41 & 32.60 \\
\hline T8 KS & 1.0 & 1.06 & 2.00 & 4.86 & 2.64 & 47.82 \\
\hline T9 KS & 1.5 & 1.06 & 2.20 & 5.40 & 2.88 & 43.08 \\
\hline $\mathrm{T} 10 \mathrm{ZnS}$ & 0.25 & 1.43 & 4.46 & 5.53 & 3.81 & 24.70 \\
\hline $\mathrm{T} 11 \mathrm{ZnS}$ & 0.50 & 1.16 & 2.00 & 5.53 & 2.90 & 42.68 \\
\hline $\mathrm{T} 12 \mathrm{ZnS}$ & 0.75 & 1.70 & 3.40 & 5.86 & 3.65 & 27.86 \\
\hline T13 NaB & 0.25 & 1.30 & 2.93 & 4.40 & 2.87 & 43.28 \\
\hline $\mathrm{T} 14 \mathrm{NaB}$ & 0.50 & 1.60 & 3.26 & 4.66 & 3.17 & 37.35 \\
\hline T15 NaB & 0.75 & 1.23 & 2.60 & 3.86 & 2.56 & 49.40 \\
\hline $\mathrm{T}$ check & - & 2.06 & 6.13 & 7.00 & 5.06 & - \\
\hline $\begin{array}{l}\text { Mean C.D. } \\
\text { at 5\% }\end{array}$ & & 1.20 & 2.84 & 5.36 & & \\
\hline Treatment & & & & & 0.74 & \\
\hline Interval & & & & & 0.32 & \\
\hline Interaction & & & & & 1.28 & \\
\hline
\end{tabular}


Table 3. Effect of some non-conventional chemicals on disease severity of alternaria blight on leaf at different stages of growth of mustard.

\begin{tabular}{|c|c|c|c|c|c|c|}
\hline \multirow[t]{2}{*}{ Treatment } & \multirow[t]{2}{*}{ Concentration (\%) } & \multicolumn{2}{|c|}{ Disease index } & \multirow{2}{*}{$\frac{(\%)}{50 \mathrm{DAS}}$} & \multirow[t]{2}{*}{ Mean } & \multirow{2}{*}{$\begin{array}{l}\text { Percent increase } \\
\text { or decrease over } \\
\text { check }\end{array}$} \\
\hline & & 30 DAS & 40 DAS & & & \\
\hline $\mathrm{T} 1 \mathrm{CaS}$ & 0.5 & $\begin{array}{l}3.00 \\
(19.34)\end{array}$ & $\begin{array}{l}8.00 \\
(16.40)\end{array}$ & $\begin{array}{l}28.00 \\
(31.79)\end{array}$ & $\begin{array}{l}13.00 \\
(19.18)\end{array}$ & 59.51 \\
\hline $\mathrm{T} 2 \mathrm{CaS}$ & 1.0 & $\begin{array}{l}4.00 \\
(11.47)\end{array}$ & $\begin{array}{l}11.00 \\
(19.35)\end{array}$ & $\begin{array}{l}44.00 \\
(41.53)\end{array}$ & $\begin{array}{l}19.66 \\
(24.12)\end{array}$ & 38.77 \\
\hline T3 CaS & 1.5 & $\begin{array}{l}5.66 \\
(13.75)\end{array}$ & $\begin{array}{l}10.00 \\
(18.37)\end{array}$ & $\begin{array}{l}38.66 \\
(38.44)\end{array}$ & $\begin{array}{l}18.11 \\
(23.52)\end{array}$ & 43.60 \\
\hline T4 Kl & 0.5 & $\begin{array}{l}1.66 \\
(6.03)\end{array}$ & $\begin{array}{l}15.66 \\
(23.30)\end{array}$ & $\begin{array}{l}52.00 \\
(46.15)\end{array}$ & $\begin{array}{l}23.11 \\
(25.16)\end{array}$ & 28.02 \\
\hline T5 Kl & 1.0 & $\begin{array}{l}3.33 \\
(10.40)\end{array}$ & $\begin{array}{l}10.66 \\
(19.04)\end{array}$ & $\begin{array}{l}46.66 \\
(43.08)\end{array}$ & $\begin{array}{l}20.22 \\
(24.17)\end{array}$ & 37.02 \\
\hline T6 K1 & 1.5 & $\begin{array}{l}4.66 \\
(12.41)\end{array}$ & $\begin{array}{l}18.66 \\
(25.59)\end{array}$ & $\begin{array}{l}44.00 \\
(41.54)\end{array}$ & $\begin{array}{l}22.44 \\
(26.51)\end{array}$ & 30.11 \\
\hline T7 KS & 0.5 & $\begin{array}{l}3.00 \\
(9.88)\end{array}$ & $\begin{array}{l}12.00 \\
(20.22)\end{array}$ & $\begin{array}{l}42.66 \\
(40.77)\end{array}$ & $\begin{array}{l}19.22 \\
(23.62)\end{array}$ & 40.14 \\
\hline T8 KS & 1.0 & $\begin{array}{l}3.33 \\
(10.49)\end{array}$ & $\begin{array}{l}10.66 \\
(19.04)\end{array}$ & $\begin{array}{l}40.00 \\
(39.21)\end{array}$ & $\begin{array}{l}18.00 \\
(22.91)\end{array}$ & 43.94 \\
\hline T9 KS & 1.5 & $\begin{array}{l}3.00 \\
(9.88)\end{array}$ & $\begin{array}{l}8.00 \\
(16.40)\end{array}$ & $\begin{array}{l}45.33 \\
(42.32)\end{array}$ & $\begin{array}{l}18.77 \\
(22.87)\end{array}$ & 41.54 \\
\hline $\mathrm{T} 10 \mathrm{ZnS}$ & 0.25 & $\begin{array}{l}11.00 \\
(19.32)\end{array}$ & $\begin{array}{l}22.66 \\
(28.42)\end{array}$ & $\begin{array}{l}41.33 \\
(40.00)\end{array}$ & $\begin{array}{l}25.00 \\
(29.24)\end{array}$ & 22.14 \\
\hline $\mathrm{T} 11 \mathrm{ZnS}$ & 0.50 & $\begin{array}{l}5.00 \\
(12.87)\end{array}$ & $\begin{array}{l}14.66 \\
(22.49)\end{array}$ & $\begin{array}{l}44.00 \\
(41.55)\end{array}$ & $\begin{array}{l}21.22 \\
(25.64)\end{array}$ & 33.91 \\
\hline $\mathrm{T} 12 \mathrm{ZnS}$ & 0.75 & $\begin{array}{l}4.00 \\
(11.47)\end{array}$ & $\begin{array}{l}10.66 \\
(18.98)\end{array}$ & $\begin{array}{l}56.00 \\
(48.45)\end{array}$ & $\begin{array}{l}23.55 \\
(26.30)\end{array}$ & 26.65 \\
\hline T13 NaB & 0.25 & $\begin{array}{l}7.00 \\
(15.31)\end{array}$ & $\begin{array}{l}14.00 \\
(21.93)\end{array}$ & $\begin{array}{l}33.33 \\
(35.26)\end{array}$ & $\begin{array}{l}18.11 \\
(24.17)\end{array}$ & 43.60 \\
\hline $\mathrm{T} 14 \mathrm{NaB}$ & 0.50 & $\begin{array}{l}5.00 \\
(12.74)\end{array}$ & $\begin{array}{l}14.66 \\
(22.36)\end{array}$ & $\begin{array}{l}35.33 \\
(36.46)\end{array}$ & $\begin{array}{l}18.33 \\
(23.86)\end{array}$ & 42.91 \\
\hline T15 NaB & 0.75 & $\begin{array}{l}6.66 \\
(14.95)\end{array}$ & $\begin{array}{l}14.66 \\
(22.47)\end{array}$ & $\begin{array}{l}32.00 \\
(34.42)\end{array}$ & $\begin{array}{l}17.77 \\
(23.95)\end{array}$ & 44.65 \\
\hline $\mathrm{T}$ check & - & $\begin{array}{l}11.00 \\
(19.32)\end{array}$ & $\begin{array}{l}30.00 \\
(33.17)\end{array}$ & $\begin{array}{l}55.33 \\
(48.06)\end{array}$ & $\begin{array}{l}32.11 \\
(33.52)\end{array}$ & - \\
\hline Mean & & $\begin{array}{l}5.08 \\
(12.48)\end{array}$ & $\begin{array}{l}14.12 \\
(21.72)\end{array}$ & $\begin{array}{l}42.41 \\
(40.56)\end{array}$ & & \\
\hline \multicolumn{7}{|l|}{ C.D. at $5 \%$} \\
\hline Treatment & & & & & 2.71 & \\
\hline Interval & & & & & 1.17 & \\
\hline Interaction & & & & & 4.70 & \\
\hline
\end{tabular}

$1.0 \%$ and $\mathrm{T}_{11} \mathrm{ZnS}$ at $0.5 \%\left(64.44 \mathrm{~mm}^{2}\right)$ followed by $\mathrm{T}_{4}$ $\mathrm{Kl}$ at $0.5 \%\left(49.90 \mathrm{~mm}^{2}\right)$ in comparison to check $\left(77.95 \mathrm{~mm}^{2}\right)$. The above results underline the importance of mineral nutrition as a component of disease management practices (Agrios, 2005; Hossain and Mian, 2005; Sugimoto et al., 2008; Meena et. al., 2011). The present investigation showed that foliar application of calcium sulphate showed maximum fungicidal effect against the alternaria blight of mustard. The size of spot, disease index, apparent infection rate and area under disease progress curve were recorded minimum by foliar application of calcium sulphate at $0.5 \%$ concentration. Several studies have reported that calcium applications can suppress diseases caused by several pathogens (Volpin and Elad, 1991; Conway et al., 1992; Yamazaki and Hoshina, 1995; Biggs et al., 1997).

Calcium has critical roles in cell division, cell development, carbohydrate movement, neutralization of cell acids, cell wall deposition and formation of pectate salts in the middle lamella (Huber and Arny, 1985). It has 
Table 4. Effect of some non-conventional chemicals on apparent* infection rate (r) at different stages of growth of mustard.

\begin{tabular}{lllll}
\hline Treatment & Concentration $(\%)$ & \multicolumn{2}{l}{ Apparent infection rate } & Mean \\
\cline { 2 - 4 } & & $30-40 \mathrm{DAS}$ & $40-50 \mathrm{DAS}$ & \\
\hline T1 CaS & 0.5 & 0.361 & 0.648 & 0.504 \\
T2 CaS & 1.0 & 0.440 & 0.744 & 0.592 \\
T3 CaS & 1.5 & 0.430 & 0.716 & 0.573 \\
T4 Kl & 0.5 & 0.450 & 0.780 & 0.615 \\
T5 K1 & 1.0 & 0.427 & 0.755 & 0.591 \\
T6 Kl & 1.5 & 0.554 & 0.748 & 0.651 \\
T7 KS & 0.5 & 0.447 & 0.738 & 0.592 \\
T8 KS & 1.0 & 0.427 & 0.724 & 0.575 \\
T9 KS & 1.5 & 0.361 & 0.746 & 0.553 \\
T10 ZnS & 0.25 & 0.609 & 0.736 & 0.672 \\
T11 ZnS & 0.50 & 0.507 & 0.746 & 0.626 \\
T12 ZnS & 0.75 & 0.434 & 0.792 & 0.613 \\
T13 NaB & 0.25 & 0.504 & 0.690 & 0.597 \\
T14 NaB & 0.50 & 0.507 & 0.702 & 0.604 \\
T15 NaB & 0.75 & 0.513 & 0.682 & 0.597 \\
T check & - & 0.666 & 0.796 & 0.731 \\
\hline
\end{tabular}

Table 5. Effect of some non-conventional chemicals on AUDPC of alternaria blight of mustard.

\begin{tabular}{|c|c|c|}
\hline Treatment & Concentration $(\%)$ & AUDPC (A) $(\mathrm{mm} 2)$ \\
\hline $\mathrm{T} 1 \mathrm{CaS}$ & 0.5 & 32.25 \\
\hline $\mathrm{T} 2 \mathrm{CaS}$ & 1.0 & 33.80 \\
\hline $\mathrm{T} 3 \mathrm{CaS}$ & 1.5 & 35.55 \\
\hline $\mathrm{T} 4 \mathrm{~K} 1$ & 0.5 & 49.90 \\
\hline T5 Kl & 1.0 & 48.25 \\
\hline T6 Kl & 1.5 & 42.40 \\
\hline T7 KS & 0.5 & 45.30 \\
\hline T8 KS & 1.0 & 64.45 \\
\hline T9 KS & 1.5 & 42.40 \\
\hline $\mathrm{T} 10 \mathrm{ZnS}$ & 0.25 & 45.30 \\
\hline $\mathrm{T} 11 \mathrm{ZnS}$ & 0.50 & 64.45 \\
\hline $\mathrm{T} 12 \mathrm{ZnS}$ & 0.75 & 46.25 \\
\hline $\mathrm{T} 13 \mathrm{NaB}$ & 0.25 & 46.60 \\
\hline $\mathrm{T} 14 \mathrm{NaB}$ & 0.50 & 46.45 \\
\hline T15 NaB & 0.75 & 45.10 \\
\hline $\mathrm{T}$ check & - & 77.95 \\
\hline
\end{tabular}

* Apparent infection rate computed on the basis of disease index.

been noted that the $\mathrm{Ca}^{2+}$ ion signal is one of the earliest events in challenged cells, and the signal is essential for the activation of plant defense responses such as phytoalexin biosynthesis, induction of defense-related genes, and hypersensitive cell death (Knight et al., 1991). The extent of disease reduction was related to increased calcium uptake by plants, suggesting that calcium was the effective element in reducing phytophthora stem rot in soybean (Sugimoto et al., 2008).

\section{Conclusion}

Manipulation of crop nutrition gives the farmer a valuable tool for managing crop health as well as reduced public pressure over pesticide residue in food and in the environment. 
This study showed that applications of nonconventional chemicals i.e. foliar spray of nutrient solution greatly influenced the reduction of alternaria blight disease of mustard. The foliar application of $\mathrm{CaSO}_{4}$ at $0.5 \%$ concentration induced resistance to alternaria blight significantly in comparision to different concentration of $\mathrm{KCl}, \mathrm{K}_{2} \mathrm{SO}_{4}, \mathrm{ZnSO}_{4}$, and $\mathrm{Na}_{2} \mathrm{~B}_{4} \mathrm{O}_{7}$. The findings of this work may lead to effective field strategies for the management of alternaria blight disease of mustard.

\section{REFERENCES}

Agrios, G.N. (2005). Plant pathology, 5th Edn., Elsevier Academic Publishers, California, USA, pp 922.

Biggs, A. R., El-Kholi, M. M., EI-Neshawy, S. and Nickerson, R. (1997). Effects of calcium salts on growth, polygalacturonase activity, and infection of peach fruit by Monilinia fructicola. Plant Disease, 81:399-403.

Conway, W. S., Sams, C. E., Mcguire, R. G. and Kelman, A. (1992). Calcium treatment of apples and potatoes to reduce post-harvest decay. Plant Disease, 76:329-334.

Hossain, M.S. and Mian, H. (2005). Integrated approach for the management of alternaria blight of cabbage seed crop. Bangladesh Journal of Plant Pathology, 21: 1923.

Huber, D. M. and Arny, D.C. (1985). Interactions of potassium with plant disease, In: Munson, R.D. ed. Potassium in agriculture. Madison, Wisconsin, American Society of Agronomy, pp. 667-688.

Khan, M. M., Khan, R. U. and Mohiddin, F. A. (2007) Studies on the cost-effective management of alternaria blight of rapeseedmustard(Brassicaspp.) Phytopathologia Mediterranea, 46: 201-206.

Knight, M. R., Cambel, A. K., Smith, S. M. and Trewavas, A. J. (1991). Transgenic plant aequorin reports the effects of touch and cold shock and elicitors on cytoplasmic calcium. Nature, 352:524-526.

Kolte SJ (1985) Diseases of Annual Edible Oilseed Crops, Vol II. Rapeseed-Mustard and Sesame Diseases. CRC Press, Boca Raton, Florida pp 83-122.

Kumar, D., Maurya, N., Bharti, Y. K., Kumar, A., Kumar, K., Srivastava, K., Chand, G., Kushwaha, C., Singh, S. K., Mishra, R. K. and Kumar, A. (2014). Alternaria blight of oilseed brassicas: A comprehensive review. African Journal of Microbiology Research, 8:2816-2829.

McCartney, H.A., Doughty, K.S., Morton, G., Booth, E.J.,
Kightey, S.P.J., Landon, G., West, G., Walker, K.C. and Thomas, J.E. (1999). A study of the effect of disease on seed quality parameters of oilseed rape. In Proceedings of $10^{\text {th }}$ International Rapeseed Congress 26-29 Sept. Canberra, Australia.

McKinney, H. H. (1923). Influence of soil temperature and moisture on infection of wheat seedlings by Helminthosporium sativum. Journal of Agricultural Research, 26: 195-217.

Meena P.D., Chattopadhyay, C., Kumar, A., Awasthi, R.P., Singh, R. , Kaur, S., Thomas, L., Goyal, P. and Chand, P. (2011). Comparative study on the effect of chemicals on alternaria blight in Indian mustard - A multi-location study in India. Journal of Environmental Biology, 32: 375-379.

Meena, P.D., Rani, A., Meena, R., Sharma, P., Gupta, R. and Chowdappa, P. (2012). Aggressiveness, diversity and distribution of Alternaria brassicae isolates infecting oil seed Brassica in India. African Journal of Microbiology Research, 6: 5249-5258.

Meena, P.D., Awasthi, R.P., Chattopadhyay, C., Kolte, S.J. and Kumar, A. (2010). Alternaria blight: a chronic disease in rapeseed-mustard, Journal of Oilseed Research, $1: 1-11$.

Sugimoto, T. Watanabe, K.,Yoshida, S., Aino, M. and Irie, K. (2008). Select Calcium Compounds Reduce the Severity of Phytophthora Stem Rot of Soybean. Plant Disease, 92:1559-1565

Sultana, N.A., Khan, M.A.H., Islam, M.N. and Nahar, K. (2009). Evaluation of appropriate time for the application of rovral against alternaria blight incidence and yield of mustard. International Journal of Sustainable Agriculture, 1: 20-23.

Vanderplank, J.E. (1963). Plant Diseases: Epidemics and Control. Academic Press, New York, London, pp 349.

Verma, R.P. and Saharan, G. S. (1994). Monograph on alternaria diseases of crucifers. Saskatoon Research Station, Technical Bulletin, pp 162.

Volpin, H. and Elad, Y. (1991). Influence of calcium nutrition on susceptibility of rose flowers to botrytis blight. Phytopathology, 81:1390-1394.

Wilcoxson, R.D., Skovmand, B. and Atif, A. H. (1975). Evaluation of wheat cultivars for their ability to retard development of stem rust. Annals of Applied Biology, 80: 275- 281.

Yamazaki, H. and Hoshina, T. (1995). Calcium nutrition affects resistance of tomato seedlings to bacterial wilt. Horticulture Science, 30:91-93. 